\title{
Pursuing Paradise: Jewish Travel Comics As Feminist Spiritual Quests
}

Although much has been written about the impact of Jewish culture and identity on comics and graphic novels (e.g. Baskind \& Omer-Sherman, 2010,Tabachnik 2014), to date, no culturally specific hermeneutic has been used to expand our understanding of the relationship between Jewish comics and the cultural matrix in which they are formed. In this article, I suggest ways in which Kabbalistic criticism and hermeneutics might fill this gap. All of the artists and images discussed here were featured in the touring exhibition Graphic Details, curated by Sarah Lightman and Michael Kaminer. The exhibition itself inhabited different kinds of secular and religious space, from galleries, to universities and synagogues. The relationship between space and voice are key aspects of the exhibition, as is evident from the catalogue:

For women to claim the space to self-examine in public is still transgressive... They're staking their claim to space; to the same space the men get to tell their stories (Jaffe 2010: 6).

The space of the exhibition, and the way it brought original work by leading female artists into dialogue with one another, was a radical and compelling alternative narrative of the history of comics. It seemed to me no coincidence that the work of several artists within the exhibition focussed on the relationship between physical and cultural space, and the dynamic way in which each shapes the other. This seemed a great opportunity to bring ancient and current critical theories into dialogue with one another, to revisit the 
Pardes travel story, discussed below, which shaped the very nature of 'Jewish' interpretation and reading, and explore the usefulness of a culturally specific way of reading, responding to Susan Hardy Aiken's question:How, in sum, are the symbolic formations of 'place' and 'space' marked by cultural ideologies that carry across into the places and spaces we inhabit? (Aiken 1998: 3) The question of the way our notions of space are shaped by cultural ideology becomes especially resonant when applied to the 'space' of the Middle East. I seek to explore the impact of gendered/feminist ways of seeing on these constructions, analysing the visual representations of space in comics created by women who have travelled through them, representing their own dynamic interrogation of the shifting ideological relationships between self and space.

The relationship between Kabballah, or Jewish Mysticism, and literary criticism has been well explored by Handelman (1991), Wolfson (2004) and Bloom (2005), amongst others. Usually, this scholarly mode applies literary analysis to Kabbalistic texts. The mode of reading rarely travels in the other direction. Crucially for this exploration of travel comics, the act of interpretation is described in the Kabbalah in a paradigmatic story as a journey through a physical landscape - one which changes you forever, depending on the baggage which you carry with you, and your willingness to put place yourself in dialogue with what you find there. I refer to the celebrated Kabbalistic 'travel' narrative of the Four Sages who enter The Pardes, meaning the Orchard or Paradise:

Four men entered the Pardes — Ben Azzai, Ben Zoma, Acher [The Other, that is, Elisha Ben Abuya], and Akiva. Ben Azzai looked and died; Ben Zoma looked and 
went mad; Acher destroyed the plants; Akiva entered in peace and departed in peace (Matt 2003: I 26b).

In the Kabbalistic tradition, PaRDeS became an acronym for four layers or levels of interpretation - Peshat, the literal meaning of a text, Remez, its symbolic structure, Drash, its relationship to other texts, and Sod, its mystical meaning. Each of the four sages represents a model of a particular approach, and the fate they meet acts as a critique of the potential reductiveness of that approach, if used exclusive of the others. The ways in which readers are asked to negotiate complex and contradictory meanings in Kabbalistic texts parallels the complexities of the image/text relationship. Given the way it situates figures in a landscape, their experiences shaped by their biographies, it is perhaps especially apt for exploring autobiographical graphic narratives. The holistic nature of such an approach, and the relationship between textual interpretation and identity underpins the assertion by the great thirteenth century mystic Isaac Luria that:

A man must concern himself with the four levels of the Torah, which is to say with the literal meaning, the allegorical meaning, the moral meaning and the mystical meaning. And he must bear the burden of the transmigration of the soul (gilgul) for as long as it takes him to complete all four (Vital 1967: 48f ).

It is interesting to note that Luria takes the term Drash, which translates as "to interpret", and assigns it a moral and ethical meaning, implying that the ultimate telos of this mode of Rabbinic interpretation was the desire that the reader should be changed, and live a more ethical life. He also clearly sees the relationship between the four modes as 
hierarchical, with the reader ascending through the four levels like climbing the rungs of a ladder. We begin with the literal meaning, progress to the allegorical or symbolic meaning then engage with the moral meaning, before arriving at the mystical level. Through exploring the work of artists challenging such hierarchical views, a more spatial way of applying the Pardes tool will emerge. The original Pardes story emphasizes that reading is a journey in which you risk yourself. I will explore the work of four female artists who mediate between personal and collective quests for meaning in their work, focalised through their own experiences. Just as in the original Pardes story, I will identify each with a paradigmatic perspective/mode of reading the interface between self and place, identity and history. I aim to initiate a mutually enriching dialogue, interweaving a feminist reading of the Kabbalistic story with a Kabbalistic reading of these feminist comics, which celebrate the power of Jewish narrative, symbolism and hermeneutics in subtle and surprising ways.

Sarah Glidden and Miriam Libicki visit Israel as outsiders, and write from Diasporic perspectives. At the same time, I will critique the patriarchal hegemony the ancient Pardes narrative encapsulates, still a significant feature of Israeli cultural identity. Elena Sztokman, a feminist scholar of cultural identity, argues that 'the 'Israel' that Diaspora Jews prefer to usher into their identities remains a powerfully and singularly male construct' (Sztokman 2007:164). Glidden struggles with this received ideology on a Zionist Birthright tour, whereby American Jewish teenagers who have not visited Israel before are given a subsidised tour of the company accompanied by trained guides, receiving a particularised narrative to contextualise their experience. In contrast Libicki 
seeks to embed herself in the ultimate symbol of that masculinity, the army, in order to pass as 'fully Israeli'. In addition to deconstructing this masculine construct from a Diasporic perspective, I was fascinated by the way the Diaspora is viewed from an Israeli perspective, and to expand the notion of 'travel' to include physical, psychological, emotional and historical landscapes, as suggested by the Kabbalistic Pardes narrative. These modes, while culturally conditioned, are not themselves "Jewish", so this model might productively be exported more widely to reading comics which articulate these themes. There is a particular resonance, and relevance, to exploring them through the visualised journeys of Jewish women.

Israeli artists Racheli Rottner and Illana Zeffren counter these Diasporic visions of faith and identity, and provide alternative models of cultural critique and religious dialogue. Given the contested nature of spatial identity in Israel, and of Israel for the diaspora, I was interested to explore the relationship between the constructions of space, self and cultural identity in the work of these artists through apposite critical frameworks. Feminist cultural geography explores the relationships between geography and gender, physical and psychological space (Bridger 2013: 287), while Rob Shields argues that analysis of 'space' must focus on its 'emotional geography' (1991: 6). I thus analyse the gendered construction of space in both Israel and the Diaspora, as presented in these four comics. I animate a close reading of key passages from their work with a parallel discussion of the way each might embody a mode of reading from the original Pardes story, contrasting the experiences of contemporary comic artist and ancient rabbinic sage. 
I will invert Luria's hierarchic ladder, beginning at the heart of the matter, with 'Sod', and end at the ostensible surface, or 'Peshat'.

\section{Sarah Glidden: The Traveller as Mystic}

Sarah Glidden’s graphic novel How to Understand Israel in 60 days or Less (2010) began as a self-published, black and white zine, before being picked up by mainstream publisher Vertigo and re-released in full colour. The Graphic Details exhibition allowed the viewer to experience Glidden's original material, and this is the work I analyse. Glidden depicts what Tresa Grauer defines as a 'performative ritual - or rite of passage that provides a kind of cultural literacy and marks the character as Jewish...Travel to Israel can also be a spiritual pilgrimage, undertaken in the hope of finding religious coherence and meaning' (2001:241). In visually representing her own spiritual quest, Glidden seeks to both interrogate and contextualise her own subjectivity, expanding it to include 'other' discourses.

Glidden chooses to depict her character's first encounter with the country bathetically. We move from street signs depicting German products, to a disembodied voice calling Sarah’s name in the first two panels comes from inside a shawarma café (2010: 3). Its sign is depicted in Hebrew alone, resisting the gaze and understanding of the cultural outsider. Rather than a Divine summons of her biblical namesake, this voice belongs to a friend who is waiting to use the toilet. Inside, Glidden struggles with the two handles of the toilet, and the double-ness of her identity. Her playful devalorization of the oracular 
continues as the toilet roll answers her questions and doubts, contrasting her experience of the plenitude of water in the US with its paucity in Israel. The depiction of private space is quietly and playfully subversive here, presenting a private yet universal activity that cuts across political boundaries. Glidden hints that bodies can escape the external political perspective embodied in her depiction of the café. The café is drawn as an external space, and from an external viewpoint, while toilets reference our own internal spaces, and bodily needs we all share wherever we live in the world. Glidden's celebration of internal, bodily spaces contrasts sharply with the rejection of the body by Ben Azzai in the patriarchal parable. This opening sequence suggests that embodiment, and the meeting of body and ideology, will be the fulcrum of her cultural critique. Her protagonist is not yet sure how to enact this critique, she only knows that this is a possibility.

In the Kabbalistic PaRDeS narrative, the mystical level of interpretation, known as Sod, or 'secret', is embodied by Simeon ben Azzai, who 'looks and dies'. Ben Azzai was celebrated for the intensity and focus of his study. His love of study induced Ben Azzai to remain unmarried; his erotic yearnings became wholly subsumed in his textual quest: When reproved for this contradiction between his life and his teachings, he replied: 'What shall I do? My soul clings lovingly to the Torah; let others contribute to the preservation of the race' (Sotah 4b). Ben Azzai's substitution of scholarship for sex, and resultant eroticised relationship with the text, at the expense of human relationships, suggests that 'looked and died' refers to the death of his body. It can also be read metaphorically; Ben Azzai's lack of human connection means he has no basis for a 
relationship with the divine 'other' and is therefore unable to ground this experience in his conscious life; the experience 'dies', it has no relational life to infuse and invigorate.

Glidden’s ‘death’ is, happily, more a death of ideology, of her preconceptions - although in the double page spread I will discuss, the boundaries of her body seem to blur into her surroundings, and she becomes an eye/I in the landscape. This enables her, and the reader, to gradually move beyond the (male) constructions of Diasporic/Israeli identity to something more culturally nuanced and complex. Glidden depicts this transformation in a bravura sequence in her bedroom in a Galilee guesthouse (2010:52) (Figure 1).

\section{PLEASE INSERT FIGURE 1 HERE.}

In the first panel, the boundaries between Glidden's self and place have dissolved, and she has become a pair of eyes in the dark; an 'I' who sees - disembodied, in a way that parallels the experience of the mystic Ben Azzai in the Pardes. Glidden as narrator here makes a playfully suggestive comment about the way in which the dichotomy between physical and psychological space has become blurred; 'This place had my mind occupied' (2010: 52). This notion of 'occupied' space simultaneously recalls both her opening encounter with Israeli toilets, and the notion that Israel itself is an occupied and contested space, as well as her own preoccupation with these layers. Feminist cultural geographer Karen Olwig argues that the concept of place is 'integral to an ongoing 'hidden' discourse, underwriting the legitimacy of those who exercise power in society' (Olwig 1993:310). By dissolving our sense of space, Glidden here exposes this hidden discourse, and makes it visible. In her visual presentation of this concept on this page, the boundaries between inside and outside, self and other, past and present, are removed. 
In place of the physical and cultural boundaries represented by the walls of her room, Glidden depicts a non-hierarchical, historical landscape in which she is surrounded by previous sleepers on the site, from prehistoric Natufians, early Jews, Romans, Arab farmers to contemporary Jews. She lends creative form to the radical critical argument that 'places... have no objective reality, only intersubjective ones' (Shurmer-Smith and Hannam 1994:13). Initially, she imagines this community of sleepers scattered across the Galilee landscape in the undifferentiating darkness. In this scene, Sarah’s own outsider status, emphasised by her depiction as a single woman, the only woman not defined by a male partner or perspective like her forebears, enables her to see beyond the nationalist discourses of space and place. While Ben Azzai's solitude was solipsistic, isolationist,

Glidden puts herself in dialogue with these layers of other sleepers, her own self presentation framing these identifiable other layers, granting each its subjective space (Figure 2).

\section{PLEASE INSERT FIGURE 2 HERE}

Unlike Ben Azzai, Glidden returns us, and her protagonist, to bodily experience, and suggests that truths must be embodied. Glidden underlines the commonality and equality of shared bodily experience, noting what all people have in common as well as difference, consciously realising and fulfilling the indication of this trajectory depicted in the toilet scene at the opening of the comic. This notion of the physical world, and its visual representation in Glidden's comic as exposing a mystical, symbolic layer of reality, chimes with the articulation by Gershom Scholem, the founder of academic study of the Kabbalah, that for the kabbalist: 
...All of creation is only a language, a symbolic expression of that level which cannot be apprehended by thought...The entire world is thus a symbolic body, within whose concrete reality there is reflected a divine secret (1997:160).

It is striking that Scholem chooses the word 'secret,' or Sod, to represent this mystical awareness, and to suggest that this awareness of the contiguity of all bodies is an experience of the divine. In this moment in the comic, Sarah seems to transcend temporal boundaries, embodying the epiphanic final stage in the journey of a mystic. In the words of kabbalah scholar Rachel Elior, at this highest level:

The mystic often displays mythic traits by being able to transcend boundaries between the living and the dead, to move between textual reality and physical reality, and to live through his consciousness simultaneously within the present, the past and the future (2007:78) .

In light of Sztokman's assertion of the phallic constructions of space (2007: 164), it is interesting that the Arabs and early and modern Jews are all depicted as couples sharing a bed, and thus as equivalent; only the Roman and Ottoman Imperial functionaries are depicted as solitary (and male); identified with objects that define their commercial utility; the helmet and the collector's bag. Glidden presents herself as staring back at the reader, her gaze in dialogue with ours, while the other sleepers have their eyes firmly closed, resisting our gaze. Glidden suggests that there is a way out of the dominant, hierarchical, historical discourse of reductive them/us binaries. Instead, Glidden presents a contiguous series of historical selves; she (and the reader) waits 'with' them. This visually enacts 
Tresa Grauer’s claim of a profound relationship between internal and external journeys, 'in which the voyage out into the unknown is part of a continuous unfolding narrative of self-discovery' (2001:242).

The moment of sunrise returns us to linear time, and the present, but this dawn also resonates with the power of her realisation. It is as though this is the illumination she has been waiting for, to enable her to let go of her confused and contested diasporic identity: 'as soon as the light changes/ I can go' (2010:52). The contrast between Sarah’s previous and present awareness is amplified by the way this sentence is split between the last two panels, the gutter signifying the liminal space of transformation embodied by both her comic and her room in the guest house. In her depiction of the relationship between physical space and its depiction in the visual narrative, Glidden identifies the subversive realisation of her protagonist with that of the reader. The final panel depicts her poised to emerge from the private space of her bedroom with a new awareness. Unlike the Kabbalistic sage Ben Azzai, who sought to encounter mystical meaning by rejecting his body, Glidden's character returns to her body with an enlarged sense of its vitality, of its contiguity with other bodies, past and present. In contrast to its patriarchal antecedent, her feminist mystical mode of reading is both embodied, and Universalist. The Birthright tour seeks to endorse the prevailing ideology of them/us, of might and occupation. In contrast, Glidden breaks down these boundaries, and seeks to encounter the historical and cultural other from a position of empathy.

\section{Miriam Libicki: The Re-Membered Self}


In Jobnik! (2008) published independently by her own imprint, real gone girl studios, Miriam Libicki depicts her experiences in perhaps the most archetypally 'male' institution in Israel, the army. Libicki is an outsider, her liminal role allowing her a unique perspective on the functioning of this macho micro-society. Her delicate pencil drawings and unpaginated format suggest a tentative, sketched and ongoing discourse, inviting us as readers/viewers to fill in the gaps, inviting us to share the private record a sketchbook would contain. Through her presentation of the spaces and places in which her personal relationships take place, and the appropriation of militarised spaces for personal ends, Libicki exposes the ways political ideology permeates the personal, and hints at how these spaces might be 'remodelled'. Libicki's romantic entanglement with an older soldier on her base is enacted in confined and hidden spaces, including a model $\operatorname{tank}(2008: 3)$.

From within the tank, Libicki's character looks up at the viewer, making us aware of our voyeurism, our penetration into this hidden space, visible only from above. This militarized space in which their intimacy is enacted traps and delimits her to a self defined by the male and the male gaze; her identity is now bound up with the fact that she 'has a boyfriend', despite his protestations to the contrary. He is able to be self-servingly vague about the nature of their relationship, whilst she needs clarity and definition. In this dominant central panel, Shahar buries his face between her breasts, while she looks up at the viewer, insisting we connect with her perspective while also foregrounding our role as voyeurs. In so doing she connects the spatial gaze of the reader with that of the character, and situates both within a dynamic awareness of the cultural construction of space. In this 
central panel, she subverts the monolithic phallic symbol of military might, the tank, and turns it into a womblike space for sexual encounter and exposes the patriarchal underpinnings of both military hierarchies of space and place, and their impact on gender relationships.

Foucault argued that his own spatial metaphors expressed 'the process by which knowledge functions as a form of power and disseminates the effects of power' (1980: 69). For Foucault, knowledge and power are inseparable. It is power that controls and shapes our attainment of knowledge. This enables us to understand why, seeking liberation and transformation, Miriam finds only oppression. In this panel, she seems to submit passively to her fate. For the viewer, Libicki the recollecting artist exposes the mechanisms of power and domination, and renders them vulnerable to critique. Foucault suggests that the way we experience both space and self is always ideologically determined - but that such ideology often remains hidden, out of sight, experienced by and through the body, as it is for Miriam, the new recruit. Libicki exposes the workings of this power mechanism, and provides her reader with an alternative mode of engaging with the workings of knowledge and power on the base - a gendered, spatial one.

The shifting meaning of the tank depicted here, and its connection to both geographical and emotional landscape, identifies Libicki's project as an artist with feminist engagements with space and place. We are witnessing the 'remodelling' identified by feminist geographer Kathleen Kirby: 
Feminist critics have long recognised how critical the daily interaction of subjects and their bodies in social spaces can be. The subject and its form, subjects and their natures, are tied into political commitments and ethical positions by virtue of being tied into particular material spaces... Yet space maintains a certain fluidity, a mobility: A space persists only as long as the boundary creating it is deliberately maintained, and the spaces these boundaries encircle are subject to continual remodelling (1996:18).

The Israel/Diaspora relationship is depicted by Libicki in gendered terms. But the mobility of this space, its potential for revision, are foregrounded in a key moment in the comic narrative (Figure 3). Here we discover that Libicki’s decision to join the army as a volunteer is shaped by a dialectic between the political and the personal; her mother's obsession with Rabin, the former Prime Minister murdered by a Jewish extremist. The striking panel layout of this page sets up a dialogue between physical and psychological space, between the ways in which a political institution like the army can lay claims to, and appropriate, cultural memory, in contrast to the private ways in which individuals can make these same traumatic memories meaningful. The page acts as a visual representation of the process of Drash, of the tension between the ways in which individual and group seek to appropriate traumatic moments of history for personal and national self-definition.

\section{PLEASE INSERT FIGURE 3 HERE}

The figure in the Talmudic story who embodies Drash, the Rabbinic, associative meaning, is Ben Zoma who 'looked and went mad.' Ben Zoma's erudition in the Halakah (Jewish 
Law) was such that he became an archetype in the collective imagination; 'Whoever sees Ben Zoma in his dream is assured of scholarship' (Berakhot: 57b). He was celebrated for his ability to interpret the Bible, and the Talmud comments 'With Ben Zoma died the last of the exegetes (darshanim)' (Mishnah Sotah 9:15). Surprisingly few of his exegeses have been preserved. The most celebrated is one which has made it into the Passover Haggadah. Ben Zoma interpreted the verse 'that you should remember the day when you came out of Egypt all the days of your life' (Deuteronomy 16: 3), to prove that the recitation of Shema, the daily prayer referring to the Exodus decreed in Numbers (15:3741), is obligatory both for the evening prayer and for the morning prayer; he argues that the additional word 'all' must be there to include the night. The rabbis with whom he argues suggest that 'all' means in the time of future redemption. His interpretation is accepted as law, and praised by Eleazar ben Azariah (Berakhot 5a).

What is the significance or relevance of this interpretive dispute? Here Ben Zoma takes a passage seemingly evoking the imperative to remember redemption, and applies it to the laws of prayer, insisting that the Shema prayer, which recalls the exodus from Egypt, must be said at Night. In the Jewish literary tradition, 'night' is both a temporal marker for the evening prayer, and also a psychological one, suggesting exile and loss. Ben Zoma sees the imperative to acknowledge the redemption from Egypt even at times of personal darkness and crisis, at 'night'. He seeks to put the personal in a wider context, and relate the speaker's experience of darkness to the collective experience of redemption. Everything reminds him of something else; he refuses to confront the garden as it is. The 
Rabbinic mode translates all personal experience into something national, especially experiences of darkness and despair.

Madness, the fate of Ben Zoma in the garden, suggests that there is a danger in appropriating personal suffering. The challenge of translating the immersive experience of the garden in the same way, in all its plenitude and fullness, proves too much for Ben Zoma. His ultimately sterile legalism proves an insufficient framework through which to encounter 'the garden'. The 'madness' of Ben Zoma results from a mis-match between his mode of interpretation and the reality of the environment he is trying to interpret, as he seeks to appropriate his immediate experience to embody national trauma. Through the fate of Ben Zoma in the garden, the Zohar suggests that this way madness lies.

In Figure 3 above, Libicki depicts Miriam standing to attention during a memorial service for Rabin on her base. The page layout sets up a dynamic relationship between physical and psychological space, past and present. Sharply etched panels establish a contrast between her mother's private connection with Rabin as she enacts her own memorial for him, juxtaposing it to the public and militarised display of the soldiers on the base, appropriating this tragedy for ideological ends. The progressively more intimate experience of space is paralleled with a dawning moment of realisation about the kinds of ideologically constructed and determined spaces that have led her to the present experience. The shifting visual perspective enacts a shift in our understanding of the contingent relationship between the personal and the national. This movement forward in time is also enacted as a progressive focalisation in space, as Libicki seems to understand 
her own positionality and space/place. Foucault argues that the self, like space, is a socially constructed site: 'the subject constitutes himself in an active fashion, by the practices of self' (1987:11). Yet this self-fashioning is culturally determined, shaped by 'patterns that he finds in the culture, which are proposed, suggested and imposed on him by his culture, his society, and his social group' (Foucault 1987:11). Libicki depicts her character's despairing realisation that her identity is culturally determined in this way; 'I don't belong in Israel as much as I belong to Israel,' is her accommodation between these competing visions of what Israel signifies to both diasporic and local imaginations, enacted visually through her treatment of place and space. It is a slightly despairing vision, in which she allows herself to be subsumed by a patriarchal construction of space and memory, just as she had in her interpersonal relationships. This Foucauldian insight also reflects the traditional rabbinic notion that that women 'belong' to men, and can be acquired by them, moving from father to husband. Women don't own themselves. Libicki has exposed this process, and its problematic extension to place. The artist laments the way her own co-option in this process rendered her a passive partner in her own subjugation. The reader is invited to see the madness and folly of defining the self through an obsessive focus on past trauma, just as Ben Zoma, the rabbinic sage identified with this approach to cultural interpretation, goes mad when confronted with the paradisiacal fullness of the world he has been seeking to co-opt.

Both Israel and the Diaspora are presented here as gendered spaces. On this page, Libicki depicts herself as part of different kinds of community - a sharing circle in the diaspora, trying to circumscribe their sense of loss, facing one another. This is depicted in stark 
contrast to the rigid patriarchal linearity of her army identity, in which all stand facing forward, avoiding eye contact. At the heart of this page is her mother, pictured alone in her room, communing with her own loss. This panel with her mother is Libicki’s imaged private space, evoked at the moment she hears of Rabin's death. Rabin's murder itself is presented as a gendered event too, a man's death as a catalyst for action, suggesting a dynamic where men make and cause actions and women just respond. So Miriam's mother's response is a rigidly gendered response too. In her depiction, Libicki asks the reader to mediate between gendered responses to tragedy, just as her character does. She suggests that women's cultural memories are defined by male violence; the elision of any effective feminist space also makes critique of this phallic ideology impossible. What links these panels, and the Diaspora with Israeli identity, is a shared sense of loss. It is worth noting that the Hebrew word for place, Makom, is also one of the names of God, suggesting that experiencing the divine means experiencing the immanence of place, its potentially transfiguring power. When Abraham is asked to sacrifice his son, 'He looked up and saw The Place (Hamakom) from a distance' (Genesis 22:4). This identification of God with a place of trauma is reinforced by its usage during mourning rituals. The recently bereaved are greeted with the phrase 'May The Place comfort you amongst the mourners of Zion and Jerusalem.' The comfort here is in having your own grief contextualised, in identifying with a larger historical narrative. Drash is intended to comfort. But it may end up appropriating individual grief in the service of Israeli nationalism. This page renders visible the binaries of inside and outside, public and private space, and contrasts the personal and collective ideologies that depend on them. 
Libicki's coming to terms with her own cultural identity enable her to articulate and enact, both visually and verbally, her own 'discrepant attachments,' (Clifford 1992:110) and her insistence on a liminal perspective at odds with the normative patriarchal perspectives which seek to silence her. For example, on the base, her duties include the incineration of potentially critical material, which she is forced to do alone. The subjugation of a female soldier, her reduction to a utilitarian tool, a 'jobnik', represented by the lowercase title of her graphic novel, is identified with the suppression of potentially critical texts by the military establishment. In her visual representations, Libicki exposes the way gendered power dynamics shape both interpersonal relationships and the basis of diaspora-Israeli identities. Madness, the fate of Ben Zoma in the garden, suggests that there is a danger in subsuming personal suffering in the collective. The challenge of translating the immersive experience of the garden in the same way, in all its plenitude and fullness, proves too much for Ben Zoma. His nationalistic discourse proves an insufficient framework through which to encounter 'the garden'.

On close reading, the subversive potential of both Libicki and Glidden's depictions of the subjective construction of space and place are evident. Maria Lugones argues that:

Each one of us occupies our place on the map in tension and resistance. When we look at ourselves and others on the map through resistant eyes, we see ourselves both as trespassers and followers of intentions that do not mesh with the logic of obedience (1998:50).

The feminist depiction of space by Libicki and Glidden and their subversion of the monolithic representation of Israel by the Diasporic imagination fulfils Lugones' 
visionary aim for a feminist geography which 'opens up the possibility of a practice of collective transformation that does not torture us into simple fragmented identities and does not abandon a politics of identity. Rather, it allows a transformation from fragmentation into complex, non-fragmented identities' (1998:50). Glidden and Libicki’s work embodies a deeply challenging and radical movement away from received notions of home and homeland, in which 'no place is 'home' though maybe it is a base...a place for conflicted, hard-earned solidarity and for contestation of meaning' (Lugones 1998:51).

\section{Racheli Rottner: The Dangerous Delights of Difference}

In the story of the four, the symbolic approach, associated with the unconscious, is associated with 'Acher' (the other, the heretic, short for Davar Acher, a forbidden word, something or someone which should not be spoken about). His real name was Elisha ben Abuya. The Jerusalem Talmud has an intriguing anecdotal account as to how his heresy came about, which, tellingly, uses the associations between children and death to generate its symbolic framework:

How did Elisha fall into heresy? It once happened that he was sitting studying in the valley of Gennesaret. He saw a man climb to the top of a tree [where there was a bird's nest containing a mother and her chicks]. The man took both the mother and her chicks, and climbed down safely. The next day he saw another man climb to the top of a tree, take the chicks only, and release the mother. When the man reached the ground, a snake bit him and he died. Elisha recalled that the Bible says: You must certainly set the mother free, and take only the chicks. Thus 
you will have a good life and a long one [Deuteronomy 22:7]. What happened, he wondered, to this man's good life? What happened to his long life?

(Hagigah: 9b)

This parable identifies Elisha's heresy with the problem of theodicy; how to believe in a good God when the innocent suffer. The commandment to shoo away the mother bird is one of the very few for which the bible specifies a reward of long life for their fulfilment. Seeing this as a sign of God's absence in the world, he rejects God entirely, and becomes known as 'The Other', a marginalised figure, whose identity has been effaced. In the garden, he acts out a sense of rage and frustration, and 'destroys the plants', angry that the basis of belief might be 'helpful fictions' that minimise suffering and loss. What is striking and illuminating in this religious paradigm is the way it includes the perspective of the Other, of Acher, as integral to any balanced view of reality, and to its full experience. The Other must be include on any journey to Paradise.

The challenges created in articulating this perspective are at the heart of Racheli Rottner's vivid, unsettling graphic novel The Other Side of the World (Rottner 2008), published by a mainstream literary imprint in Israel, but not yet available in English. I translated the extracts featured in the Graphic Details exhibition, and wrote about my first encounter with her work in the Eisner winning book accompanying the exhibition (Lightman 2014:269). All translations cited here are therefore my own. Rottner appropriates and inverts Grauer's notion of spiritual pilgrimage from the Diaspora to the Holy Land. She feels in exile within Israel, and journeys to the diaspora in search of her 
own spiritual and psychological wholeness, replacing a communal and nationalist ideology with her own revisionist agenda.

The only moment the landscape becomes figurative in the Pardes is as a projection of Acher's unease. Rottner's internal sense of displacement and exile are embodied in a symbolic dream figure, Thistlehedge. As his name suggests, Thistlehedge is a character formed of a plant used to demarcate borders and boundaries. He is an interloper to her unconscious from an Australian science fiction TV programme she has been watching. Crossing over from her conscious to her unconscious life, his blurred outline seems to represent the potentially unsettling interactions between bodily space and physical space. Every night, just like Abuya, Rottner’s protagonist literally and figuratively 'destroys the plants', killing Thistlehedge, seeking to eliminate the sense of liminality and alienation he embodies. Her unconscious 'I' is literally an 'other'.

Kathleen Kirby argues that a fundamental element in the construction of identity is in the way 'we maintain a mental separation between the two worlds of expression and reality' (1996: 5). In the adult life of Rottner's protagonist, the boundaries between this imagined nocturnal kingdom over which she exerts control, and her waking life become increasingly fluid. Once she has taken the dangerous step of embracing him, rather than seeking to destroy him, Thistlehedge crosses back over to her conscious life. Having broken through this boundary, Thistlehedge disappears altogether. Without his dark otherness, Rottner's protagonist has no idea who she is. Haunted by a sense of loss, she undertakes a therapeutic journey to Sydney, Thistlehedge's (fictional) address given in 
the TV series. When she reveals what she is looking for, guests at the hostel where she is staying laugh at her, and suggest this is a naïve and childish journey: 'You are going to a place that doesn't exist! How old are you anyway?' (Rottner 2008:53). Rottner's argument is that every journey is precisely a confrontation with unconscious, a 'place which doesn't exist,' yet which shapes our experience of the real.

Proving both resourceful and tenacious in her quest, she manages to track down the filmmaker of the series, eleven years on. He walks her around the Sydney of the show, including Thistlehedge's house, which she is shocked to find inhabited. Real and imaginary constructions of space cut against one another, and she finds the tension unbearable and flees. In this moment, her engagement with Thistlehedge embodies her struggle with her own sense of difference and embodiment. Reflecting on her reaction, the protagonist muses on her own fictionality, her constructed nature, and the way in which individual and collective identity are predicated on being attacked/saved by an imaginary 'other'. She draws parallels between her own predicament and that of the Lubavitch Hassidic community who host her for Sabbath meals while she is in Sydney. They actively yearn for a religious messiah, who will allow them to 'return' to Israel. They 'were waiting for the Messiah, and knew who he was', while she 'began to think that he (Thistlehedge) might not show up...that maybe he never existed...that neither of us did' (Rottner 2008:54).

Creating a subversive parallel between the Messiah and Thistlehedge, Rottner 'heretically' suggests that we project our longing for personal redemption on imagined 
figures. But rather than this being a source of anxiety, anger, or despair, Rottner suggests that acknowledging the way unconscious and personal symbolism, or Remez, might act as the building blocks of a new kind of identity. She has left Israel for the diaspora to make sense of her exile from herself, and come to terms with her lack of certainty, her refreshing refusal to demarcate boundaries with certainty. In the final part of the narrative, her sense of redemption comes not despite her sense of fragmentation in space and time, but by acknowledging it. She embraces doubt as a mode of being.

Her visit is meant to culminate in a meeting with the actor who played Thistlehedge in the series. But in the event he does not appear, as he has not aged well, and prefers for her to hold on to her image of him rather than become disillusioned by the gap between her idealised image of him and his present ravaged decrepitude. It is paradoxically in this moment of his absence that Rottner's protagonist discovers a deeper kinship with him, realises the extent to which he is her own projection (Figure 4).

\section{PLEASE INSERT FIGURE 4 HERE}

Initially, the actor and Rottner's protagonist exist in separate spaces, yet their identical shadows, in the same white space of the floor, reach towards one another. In contrast to Abuya in the parable, she does not 'destroy the plants', despite her disappointment at his no-show. Instead, Rottner depicts the gradual layering/covering of the actor with his persona, as the man becomes obscured by a veil of plants, which then extend to cover her as well. Our gradual experience of this process as readers parallels the protagonist's realisation that she is also Thistlehedge; 'Through the fog of disappointment, something 
had changed. When I realised how much the person behind Thistlehedge's character was like me' (Rottner 2008:54). This acceptance and identification of transfiguring difference is enacted spatially; the boundaries between the two figures break down, and they walk hand in hand across a landscape so minimally depicted it too is clearly a suggestion, a construction, the figure of figures in a landscape. For it is the relation between figure and landscape that is being depicted.

In this way, perhaps, Rottner does indeed 'destroy the plants,' cutting down the demarcating boundaries between self and other. Her protagonist, and her narrative, acknowledge this binary as an artificial construction. Breaking down the plants has become a mode of healing and of identification. Maria Lugones argues that this rare open-ness to spatial and psychological ambiguity that is a hallmark of truly feminist travel writing:

To take such political action, you must be willing to adopt an epistemic attitude of being comfortable with uncertainty, moving in and out of places here you do not know what is going to happen (1998:51).

Rottner's work articulates a politics of identity which embraces the other in all its uncertainty and subjectivity, redeeming the other as the source of self and indeed, of the possibility of redemption. This is a recurrent trope in the thinking of Jewish philosopher Emmanuel Levinas, who writes:

The first revelation of the other, presupposed in all the other relations with him, does not consist in grasping him in his negative resistance and in circumventing 
him by ruse. I do not struggle with a faceless God, but I respond to His expression, to His revelation (1969:197).

\section{Illana Zeffren: Literalism, Love and the Possibility of Wholeness}

Ilana Zeffren is a celebrated lesbian activist and journalist. Her one-page comics, "Rishumon,” serialised in several Israeli newspapers, have brought her irreverent, nonnormative perspective into the Israeli mainstream, with similar impact to Alison Bechdel's Dykes to Watch Out For. They have now been collected and published as an anthology by an Israeli publishing house (2014). Her graphic novel "Sipur Varod" or "Pink Story" (2005), tells the story of the LGBT community in Israel, interwoven with the personal story of Zeffren herself. In Rishumon, her carefully observed vignettes, explore wider cultural and political spaces through the depiction of her own domestic space. They embody scholar Mary Louise Pratt's view of the feminist depiction of domestic space as a 'mode of constituting knowledge and subjectivity'(1992:159). In Zeffren's work, the space of her Tel Aviv apartment acts as a tool for critiquing the ideologies of politics and gender. Seemingly occurring on a mundane level, the level of 'Peshat', Zeffren's work in fact includes the other layers of associative, symbolic and even mystical meaning we have been exploring. Familiar everyday objects from her cat's plate to the figurines on her air conditioner, become alive with symbolic meaning, as she reveals the way our personal and national histories are encoded in the objects we surround ourselves with. We will explore two of her columns, which featured in the Graphic Details exhibition, and were specially translated for it by Zeffren herself. 
In the Pardes paradigm, only Rabbi Akiva enters and leaves the Garden in peace and wholeness, (the Hebrew word for peace, 'Shalom', has the same root, 'ShLM', as 'Shalem', or whole). Akiva is considered to be one of the founders of Rabbinic Judaism. There are many stories about how this poor shepherd became the leading scholar of his day. The most dominant narrative strand in the Talmud suggests that he did it all for love: The daughter of Kalba Sabu'a betrothed herself to R. Akiva. When her father heard, he vowed that she was not to benefit from any of his property. Then she went and married him in winter. They slept on straw, and she had to pick out the straw from his hair... [Subsequently] she counselled him, 'Go, and become a scholar.' So he left her, and spent twelve years [studying] under R. Eliezer and R. Joshua. At the end of this period, he was returning home, when from the back of the house he heard a wicked man jeering at his wife, 'Your father did well to disown you. Firstly, because he [Akiva] is your inferior; and secondly, he has abandoned you to living widowhood all these years.' She replied, 'Yet were he to hear my desires, he would be absent another twelve years. Seeing that she has given me permission,' he said, 'I will go back.' So he went back, and was absent for another twelve years, [at the end of which] he returned with twenty-four thousand disciples. Everyone flocked to welcome him, including her [his wife] too. But... the disciples wished to repulse her. 'Make way for her,' he told them, 'for my [learning] and yours are hers' (Ketubot: 62b-63a).

The Talmudic tale is far from depicting an ideal relationship, recalling the steadfast love of Penelope for Odysseus. But it does suggest that Akiva engages with the tradition out of love for a woman, and that his quest for the divine emerges from this basis. He hangs the 
whole edifice of rabbinic Judaism, of which he was a primary exponent, on the act of selfless love by his wife. For while he has travelled away from home and returned a great scholar, his wife has remained confined in the domestic space, seemingly trapped by it. His disciples seek to reject this woman, and the domestic space which she is identified with, as unworthy of note. Akiva insists that everything depends on it. It is ironic that his wife, who had overturned social and class conventions by choosing him, is not named. This allows her to be more easily forgotten by his students, and the traditional reader The ways in which the past might be forgotten or remembered are at the heart of Zeffren's comics, both in the content of her work, and in the different visual styles she chooses to depict them. For example, In 'Under Spaghetti's Tuna Lies a dignified past' (Zeffren, 2006), the layers of past and present are represented in discrete visual styles, before being interwoven (Figure 5). The past is photographic, documentary, yet located within the pictorial space of the drawn comic and subsumed by it.

\section{PLEASE INSERT FIGURE 5 HERE.}

The plate belonging to her beloved ancestors is now used for her cat's food, the 'dignified' past that lies under her cat's plate. This re-appropriation of a sacred past for domestic use is not an act of desecration, but has a poetic appropriateness, as we learn that the grandmother who is identified with the plate was a lover of cats and a feeder of feline outsiders. The wildness and hunger of these cats, and the loss of her own family members, are dynamically present in the daily ritual of feeding her cat. Throughout Zeffren's work, her cats act as a kind of Greek chorus, both characters and commentary, inside and outside the narrative. They are figures of difference, playful stand-ins for the 
way Zeffren's lesbian politics enables her to subvert the heteronormative, subjugatory domesticity of Akiva’s origin narrative.

This is even more evident in another column, also featured in the exhibition, where Zeffren, a politically and relationally committed lesbian, laughingly muses on what might have been as she reflects on her childhood romance with a wild boy from Puerto Rico (Figure 6). In this column, she literally turns the values and dynamics of the Akiva story on their head.

\section{PLEASE INSERT FIGURE 6 HERE}

Zeffren's perspective on her sexual identity as an inversion of heteronormativity is signified by the anecdote that her boyfriend could "walk down stairs on his hands." He is a Christian from Puerto Rico, an outsider and migrant in Israel, who eventually returns home. She also playfully recalls the way Akiva finally returns home to be embraced by his wife, his potentially abusive behaviour accepted and endorsed by her. In this instance, her recounting of the past underlying her present, describes her re-encountering of her boyfriend's father. He shows her a photograph of her former partner. Once again the past is presented as a photographic record, a possible reference to the "throwaway" status of the newspapers in which these works originally featured. The father figure playfully relates that his son is still waiting to join her. But unlike Akiva, who is gratefully received by the subjugated wife who chose him, in Zeffren's comic, it is the macho, heteronormative diasporic male who is marginalised. All that is left of him, like the plate embodying her grandparents in the previous column, are two figurines of animals. 
Zeffren gives the animal figurines their own voices, acknowledging this layer of her own identity. She depicts it the social pressure of heteronormativity that she has left behind concretely, giving shape to the past on both a textual and visual level, and representing its relationship to the present in a celebratory way.

Zeffren makes space for these distinct elements of her familial and sexual past within her domestic space and her life. In the two columns discussed here, she manages to combine all four levels of the Pardes story.

The plate belonging to her grandmother and the photograph of her former boyfriend embody the layer of Drash, the mode in which the present reality gains meaning from entering into dialogue with another textual/historical reality. The moral mode, Remez is conveyed through her channelling of her grandmother's kindness in feeding street cats as she gives food to her own. Sod, the mystical possibility of a world in which everything has a voice, hinted at in the beginning of Glidden's graphic novel with the speaking toilet, returns vividly here, with the choric role of her cats, and the speaking figurines. The potential for the graphic depiction of real domestic space, Peshat, to function as a model for personal wholeness and fulfilment, first suggested by Glidden's nocturnal vision graphic novel, is realised in the everyday waking world of Zeffren's columns. Her delightful comics take us back and forth between the past and the present, Israel and the Diaspora, Zeffren makes her readers accomplices, fellow travellers, and reveals the wholeness possible within a mundane present that can reach accommodations with the multiple voices of the past. 
In these diverse works, the artists release the elided and supressed histories of place and self, breaking down such binary oppositions and celebrating the intra-subjectivities of personal and physical space. Sarah Glidden briefly establishes a non-hierarchical, pluralist sense of identity that acknowledges the historical 'Other'. I' argue that her approach mirrors the mystical approach to narrative interpretation from the Pardes, the rabbinic journey narrative that encodes a four-layered hermeneutic. Miriam Libicki exposes the dangers of the 'Drash' approach, which seeks to co-opt individual suffering and make political capital from it - she sees it as co-extensive with the patriarchal subjugation of her protagonist in the army. Rachel Rottner is more subversive, moving away from Israel to discover how deeply subjective our sense of home might be and the extent that it is open to reinterpretation - and that it is in fact a symbolic construction, corresponding to Remez in the rabbinic mode based on an effacement of the Other. Ilana Zeffren, an armchair traveller, re-appropriates the hallowed relics of her family past, and in so doing seems to liberate their true meaning. Zeffren's work has the playfulness and confidence to incorporate multimodal ways of being and seeing to represent those layers of identity. The space within and the space around us enter into productive dialogue in the work of these trailblazing artists, who collectively embody exciting possibilities for the understanding of place, both within comics and our cultural and personal lives.

\section{Works Cited:}

Aiken, S.H. (1998) Making worlds : Gender, Metaphor, Materiality. Tucson: University of Arizona Press. 
Baskind S. \& Omer-Sherman, R. (2010) The Jewish Graphic Novel: Critical Approaches Rutgers University Press.

Bloom, H. (2005) Kabbalah and Criticism. Continuum Press

Bridger, A.J. (2013) 'Psychogeography and feminist methodology'. Feminism \& psychology : an international journal 23, no 3: 285-98.

Clifford, J. (1992) 'Travelling cultures.' In Cultural studies, eds Grossberg, L, Nelson, C and Treichler, Pa, London: Routledge. (96-112).

Epstein, I. \& I. W. Slotki. Trans. (1983) Tractate Ketubot Hebrew-English Edition of the Babylonian Talmud. London: Soncino Press

Epstein, I. \& I. W. Slotki. Trans. (1984) Tractate Hagigah Hebrew-English Edition of the Babylonian Talmud. London: Soncino Press

Epstein, I. \& I. W. Slotki. Trans. (1985) Tractate Sotah Hebrew-English Edition of the Babylonian Talmud. London: Soncino Press

Epstein, I. \& I. W. Slotki. Trans. (2006) Tractate Berakhot Hebrew-English Edition of the Babylonian Talmud. London: Soncino Press

Elior, R. (2007) Jewish Mysticism: The Infinite Expression of Freedom. Eds. Nave, Yudith and Arthur B. Millman. Oxford: Littman Library of Jewish Civilization.

Fisch, H. Ed. (1989) Jerusalem Bible. Jerusalem: Koren,

Foucault, M. (1980). Questions on geography. In Power/knowledge: Selected interviews and other writings, 1972-1977, ed. Gordon, C,. New York: Pantheon. (63-77)

Glidden, S. (2010) How to understand israel in 60 days or less. New York: DC Comics.

Grauer, T. (2001) 'A drastically bifurcated legacy: Homeland and jewish identity in contemporary jewish american literature.’ In Divergent Jewish Cultures : Israel and America, eds Moore, D and Troen, S, New Haven; London: Yale University Press. (238-55)

Handelman, S.A (1991) Fragments of Redemption: Jewish Thought and Literary Theory in Benjamin, Scholem and Levinas. John Wiley \& Sons

Kehati, P. Trans. (1994) Mishnah Sotah Eliner Library: World Zionist Organisation

Kirby, K.M. (1996) Indifferent Boundaries: Spatial Concepts of Human Subjectivity. New York ; London: Guilford Press.

Levinas, E. (1969) Totality and Infinity: An Essay on Exteriority. Trans. Lingis, Alphonso. Pittsburgh: Duquesne University Press.

Libicki, M. (2008) jobnick! Vancouver, British Columbia: Real Gone Girl Studios.

Lightman, S. Ed. (2014) Graphic Details: Jewish Women's Confessional Comics an Essays and Interviews. Jefferson, NC: McFarland

Lugones, M. (1998) 'Motion, stasis and resistance to interlocking oppressions.' In Making Worlds : Gender, Metaphor, Materiality, eds Aiken, Sh, Brigham, A, Marston, Sa and Waterstone, P, 49-52. Tucson: University of Arizona Press.

Matt, D. (2003). The Zohar. Stanford, Calif.: Stanford University Press

Mills, S. (1994) 'Knowledge, gender and empire.' In Writing Women and Space : Colonial and Postcolonial Geographies, eds Blunt, A and Rose, G,. New York ; London: Guilford Press. (29-50)

Moses, S. (1999)"Gershom Scholem's Reading of Kafka: Literary Criticism and Kabbalah." New German Critique 26: 149-67. 
Neusner, J. (1988) Mishnah Yadayim in The Mishnah: A New Translation. Yale University Press.

Olwig, K. (1993) 'A sexual cosmology: Nation and landscape at the conceptual intersitces of nature and culture; or what does landscape really mean?' In Landscape : Politics and Perspectives, ed. Bender, B. . Providence, R.I. ; Oxford: Berg. (307-43)

Pratt, M.L. (1992) Imperial Eyes : Studies in Travel Writing and Transculturation: Routledge.

Rottner, R. (2008) The Other Side of the World. Tel Aviv: Babel.

Scholem, G. (1997) On the Possibility of Jewish Mysticism in Our Time \& Other Essays. New York: Jewish Publication Society

Shields, R. (1991) Places on the Margin : Alternative Geographies of Modernity. London: Routledge.

Shurmer-Smith, P. and K. Hannam. (1994) Worlds of Desire, Realms of Power : A Cultural Geography. London: Edward Arnold.

Sztokman, E. (2007) 'Gender and Israel in diaspora Jewish identity.' In Israel, the Diaspora, and Jewish Identity, eds Ben-Moshe, D and Segev, Z. Brighton: Sussex Academic. (164-75)

Vital, C. (1963) Isaac Luria's Shaar Ha-Gilgulim: The Gates of Reincarnation. Trans. Tel Aviv: Ashlag

Wolfson, E.R (2004) Language, Eros, Being: Kabbalistic Hermeneutics and Poetic Imagination. Fordham University Press

Zeffren, I. (2005) Sipur Varod (Pink Story) Tel Aviv: Mapa, (in Hebrew)

Zeffren, I. (2014) Rishumon Tel Aviv: Pardes (in Hebrew). 